\title{
AKTIVITAS BELAJAR SISWA PADA PRAKTIKUM PENGINDERAAN JAUH DI SMA
}

\author{
Okta $^{1}$, Murjainah $^{2}$, dan Edi Harapan ${ }^{3}$ \\ ${ }^{1,2,3}$ Prodi Pendidikan Geografi, FKIP Universitas PGRI Palembang
}

\begin{abstract}
Berdasarkan data yang diperoleh dari wawancara peneliti dengan guru mata pelajaran Geografi kelas X SMA Negeri 3 Tebing Tinggi diketahui bahwa aktivitas belajar siswa pada materi praktikum penginderaan jauh siswa cukup aktif. Hal ini dikarenakan dalam pembelajaran pada proses tersebut, guru menggunakan metode konvensional atau pembelajaran yang masih sebatas memperkenalkan citra penginderaan jauh tanpa adanya praktikum. Aktivitas siswa dalam belajar akan menjadi fokus untuk mengetahui aktivitas dalam praktikum penginderaan jauh. Rumusan masalah penelitian ini adalah tentang aktivitas belajar siswa pada praktikum penginderaan jauh di SMA Negeri 3 Tebing Tinggi. Tujuan penelitian ini adalah untuk untuk mengetahui dan menganalisis aktivitas belajar siswa pada praktikum penginderaan jauh di SMA Negeri 3 Tebing Tinggi. Metode yang digunakan adalah metode deskriptif kualitatif. Data penelitian diperoleh dari data primer yaitu hasil penilaian aktivitas belajar siswa Pengumpulan data menggunakan lembar observasi, wawancara, dan dokumentasi. Teknik analisis data menggunakan persentase yang selanjutnya dideskripsikan berdasarkan hasil yang diperoleh. Berdasarkan hasil penelitian dapat disimpulkan bahwa rata-rata persentase indikator 1 yaitu aktivitas visual sebesar $67,19 \%$, rata-rata persentase indikator 2 yaitu aktivitas lisan sebesar $61,46 \%$, rata-rata persentase indikator 3 yaitu aktivitas menulis sebesar $65,37 \%$, dan rata-rata persentase indikator 4 yaitu aktivitas berpikir sebesar $63,54 \%$. Secara keseluruhuan dapat diketahui bahwa rata-rata aktivitas siswa pada pertemuan I sebesar 46\% (kategori kurang aktif), pertemuan II sebesar $56 \%$ (kategori aktif), dan pertemuan III sebesar 92\% (kategori sangat aktif).
\end{abstract}

Kata Kunci: Aktivitas Belajar, Praktikum, Penginderaan Jauh

\section{A. PENDAHULUAN}

Pembelajaran geografi hakikatnya adalah pembelajaran tentang aspekaspek keruangan permukaan bumi yang merupakan keseluruhan gejala alam dan kehidupan umat manusia dengan variansi kewilayahan. Pembelajaran geografi di sekolah merupakan pembelajaran yang meliputi aspek-aspek

Korespondensi:

e-mail: murjainah@gmail.com keruangan, kelingkungan, dan kewilyahan dengan objek studi geografi adalah geosfer yang terdiri atas atmosfer, litosfer, hidrosfer dan biosfer yang disesuaikan dengan tingkat perkembangan psikologi siswa pada jenjang-jenjang pendidikan [1].

Permendiknas nomor 22 tahun 2006 tentang standar isi menjelaskan 
bahwa tujuan pembelajaran geografi di sekolah adalah agar siswa memiliki kemampuan sebagai berikut (1) Memahami pola spasial, lingkungan dan kewilayahan serta proses yang berkaitan; (2) Menguasai keterampilan dasar dalam memperoleh data dan informasi, mengkomunikasikan dan menerapkan pengetahuan geografi; dan (3) Menampilkan perilaku peduli terhadap lingkungan hidup dan memanfaatkan sumber daya alam secara arif serta memiliki toleransi terhadap keragaman budaya masyarakat.[2]

Berdasarkan peraturan tersebut pembelajaran geografi bertujuan membekali siswa agar memiliki pemahaman mengenai pola spasial, lingkungan dan kewilayahan serta menguasai keterampilan dasar dalam memperoleh data dan informasi sehingga mampu menumbuhkan perilaku peduli terhadap lingkungan sekitar. Sikap peduli terhadap lingkungan sekitar ini tercermin pada melestarikan lingkungan hidup.

Berdasarkan data yang diperoleh dari wawancara peneliti dengan guru mata pelajaran Geografi kelas X SMA Negeri 3 Tebing Tinggi diketahui bahwa aktivitas belajar siswa pada materi praktikum penginderaan jauh siswa cukup aktif. Hal ini dikarenakan dalam pembelajaran pada proses tersebut, guru menggunakan metode konvensional atau pembelajaran yang masih sebatas memperkenalkan citra penginderaan jauh tanpa adanya praktikum. Dalam pelaksaan peraktikum melibatkan siswa kelas $\mathrm{X}$ dalam belajar atau memberikan pengalaman langsung kepada siswa melalui praktikum penginderaan jauh, dari praktikum tersebut akan terlihat aktivitas siswa dalam belajar. Aktivitas siswa dalam belajar akan menjadi fokus untuk mengetahui aktivitas dalam praktikum penginderaan jauh.

Secara harfiah, kata praktikum merupakan "aktif", sedangkan dalam bahasa Inggris, kata praktikum bermakna sama dengan excersice atau exercise yang secara harfiah berarti "tetap aktif/sibuk" yang bermakna sama dengan "latihan" atau "response". Praktikum Penginderaan Jauh adalah materi yang menjelaskan tentang cara memperoleh data atau informasi tentang objek, gejala atau daerah dengan sensor buatan, tanpa kontak langsung [3].

Hasil penelitian Murjainah (2018) menunjukkan bahwa selama praktikum mahasiswa diberikan pengarahan dan penjelasan dalam mengaplikasikan peta dengan menggunakan program Arcgis dimulai dari meng-input peta ke dalam program Arcgis, menentukan 
georeference, digitasi peta, labelling, layout, serta menganalisis data spasial berupa foto udara area Universitas PGRI Palembang yang bersumber dari google earth. Hasil analisis data menunjukkan bahwa ada pengaruh praktikum SIG terhadap kemampuan spasial mahasiswa pendidikan geografi dalam membuat peta berbasis Arcgis pada mata kuliah Sistem Informasi Geografi tahun ajaran 2015/2016. Ini dibuktikan dengan hasil nilai rata-rata kelas 82,61. [4]

Menurut Streibel dalam Supinah, aktivitas belajar siswa terutama di kelas lebih ditekankan kepada interaksi antara guru dengan siswa, antara siswa dengan siswa atau antara siswa dengan media instruksional. Aktivitas belajar siswa yang baik dapat terjadi apabila guru mengupayakan situasi dan kondisi pembelajaran yang mendukung. Upaya terebut meliputi: (a) perencanaan pembelajaran berorientasi pada kepada aktivitas siswa; (b) memuat perencanaan komunikasi tatap muka; (c) memutuskan pilihan jika terjadi suatu dilema; (d) mengembangkan situasi agar siswa terlibat dalam percakapan praktis. [5]

Penelitian ini difokuskan pada aktivitas belajar siswa pada praktikum penginderaan jauh di kelas X SMA
Negeri 3 Tebing Tinggi. Subfokus penelitian ini adalah sebagai berikut.

1) Model pembelajaran yang digunakan guru saat pembelajaran Geografi materi praktikum penginderaan jauh.

2) Media pembelajaran yang digunakan guru saat pembelajaran Geografi materi praktikum penginderaan jauh.

3) Aktivitas belajar siswa saat pembelajaran geografi materi praktikum penginderaan jauh.

Pembelajaran adalah "Suatu kombinasi yang tersusun meliputi unsurunsur manusiawi, material, fasilitas, perlengkapan dan prosedur yang saling mempengaruhi untuk mencapai tujuan pembelajaran."[6] "Istilah pembelajaran sama dengan instruction atau pengajaran. Pengajaran mempunyai arti cara (perbuatan) mengajar atau mengajarkan".[7]

"Pembelajaran ialah kegiatan guru secara terprogram dalam desain instruksional, untuk membuat siswa belajar secara aktif, yang menekankan pada penyediaan sumber belajar."[8] Dalam Undang-Undang Sistem Pendidikan Nasional No. 20 tahun 2003 dijelaskan bahwa "Pembelajaran ialah proses interaksi peserta didik dengan 
pendidik dan sumber belajar pada suatu lingkungan belajar." "Pembelajaran memiliki hakikat perencanaan atau perancangan sebagai upaya untuk membelajarkan siswa."[9]

Bila pengajaran diartikan sebagai perbuatan mengajar tentunya ada yang mengajar yaitu guru, dan ada yang diajar atau yang belajar yaitu siswa. Dengan demikian pengajaran dapat diartikan sama dengan perbuatan belajar (oleh siswa) dan mengajar oleh guru. Proses belajar mengajar yang terjadi melibatkan beberapa komponen seperti: siswa, guru, tujuan, isi pelajaran, metode, media, serta evaluasi. Proses ini juga dipengaruhi oleh faktor internal maupun eksternal yang ada pada siswa

Berdasarkan pengertian tersebut di atas maka dapat disimpulkan bahwa pembelajaran adalah kegiatan secara sadar yang dilakukan guru untuk membuat siswa belajar dengan memperhatikan komponen-komponen pembelajaran dan faktor intern maupun ekstern yang ada pada diri siswa untuk mencapai tujuan pembelajaran.

Pembelajaran geografi adalah geografi yang diajarkan di tingkat sekolah dasar dan sekolah menengah. Oleh karena itu, penjabaran konsepkonsep, pokok bahasan, dan subpokok bahasannya harus disesuaikan dan diserasikan dengan tingkat pengalaman dan perkembangan psikologi siswa pada jenjang-jenjang pendidikan.[1]

Terdapat beberapa pemahaman tentang makna penginderaan jauh. Definisi umum tentang penginderaan jauh adalah ilmu tentang perolehan informasi permukaan bumi tanpa kontak langsung dengan obyeknya. [10] Penginderaan jauh merupakan suatu proses pendugaan berbagai parameter permukaan melalui pengukuran radiasi gelombang elektromagnetik dari permukaan lahan.[11]

Apabila dilihat dari tujuannya, beberapa ahli telah memberikan penjelasannya. Tujuan pokok dari penginderaan jauh adalah untuk mengidentifikasi dan mengkarakterisasi obyek di muka bumi. Data penginderaan jauh dianalisis untuk mempertajam pemahaman tentang kondisi permukaan bumi dalam hal bentuk, komposisi dan fungsinya.[12] Pendapat lain menyatakan bahwa analisis terhadap data pengideraan jauh adalah untuk membangun hipotesa-hipotesa serta memahami dinamika objek spasial.[13]

"Aktivitas belajar merupakan aktivitas yang bersifat fisik maupun mental. Dalam kegiatan belajar keduanya saling berkaitan.”[14] “Aktivitas belajar merupakan kegiatan 
yang dilakukan oleh siswa dalam kegiatan pembelajaran.”[6]

Belajar sangat dibutuhkan adanya aktivitas, dikarenakan tanpa adanya aktivitas proses belajar tidak mungkin berlangsung dengan baik. Pada proses aktivitas pembelajaran harus melibatkan seluruh aspek peserta didik, baik jasmani maupun rohani sehingga perubahan perilakunya dapat berubah dengan cepat, tepat, mudah dan benar, baik berkaitan dengan aspek kognitif afektif maupun psikomotor.[15]

Aktivitas siswa adalah keterlibatan siswa dalam bentuk sikap, pikiran, perhatian dan aktivitas dalam kegiatan pembelajaran guna menunjang keberhasilan proses belajar mengajar dan memperoleh manfaat dari kegiatan tersebut.

Keaktifan siswa selama proses belajar mengajar merupakan salah satu indikator adanya keinginan atau motivasi siswa untuk belajar. Siswa dikatakan memiliki keaktifan apabila ditemukan ciri-ciri perilaku seperti : sering bertanya kepada guru atau siswa lain, mau mengerjakan tugas yang diberikan guru, mampu menjawab pertanyaan, senang diberi tugas belajar, dan lain sebagainya. [16]
Aktivitas artinya "kegiatan atau keaktifan". Jadi segala sesuatu yang dilakukan atau kegiatan-kegiatan yang terjadi baik fisik maupun non-fisik, merupakan suatu aktifitas.[17] Aktivitas adalah segala kegiatan yang dilaksanakan baik secara jasmani atau rohani dengan maksud aktivitas siswa selama proses belajar mengajar merupakan salah satu indikator adanya keinginan siswa untuk belajar.[16]

Berdasarkan pengertian tersebut dapat disimpulkan bahwa aktivitas belajar merupakan serangkaian kegiatan pembelajaran yang dilakukan siswaselama proses pembelajaran. Siswa melakukan berbagai aktivitas dalam kegiatan pembelajaran diharapkan siswa dapat membangun pengetahuan.

\section{B. METODE PENELITIAN}

Penelitian ini menggunakan metode deskriptif kualitatif. Metode penelitian kualitatif sering disebut metode penelitian naturalistik karena penelitiannya dilakukan pada kondisi yang alamiah (natural setting); disebut juga sebagai metode etnographi, karena pada awalnya metode ini lebih banyak digunakan untuk penelitian bidang antropologi budaya; disebut sebagai metode kualitatif, karena data yang terkumpul dan analisisnya lebih bersifat kualitatif.[18] Penggunaan metode 
deskriptif kualitatif dalam penelitian ini digunakan untuk mendeskriptifkan aktivitas belajar siswa pada praktikum penginderaan jauh di SMA Negeri 3 Tebing Tinggi.

\section{HASIL PENELITIAN DAN PEMBAHASAN}

Penelitian tentang aktivitas belajar siswa pada praktikum penginderaan jauh di SMA diukur menggunakan lembar observasi yang terdiri dari 4 indikator, yaitu aktivitas visual, aktivitas lisan, aktivitas menulis, dan aktivitas berpikir. Penelitian ini dilaksanakan pada tiga kali pertemuan.

Aktivitas belajar merupakan aktivitas yang bersifat fisik maupun mental, dalam kegiatan belajar keduanya saling berkaitan. Belajar sangat dibutuhkan adanya aktivitas, dikarenakan tanpa adanya aktivitas proses belajar tidak mungkin berlangsung dengan baik.[14] Pada proses aktivitas pembelajaran harus melibatkan seluruh aspek peserta didik, baik jasmani maupun rohani sehingga perubahan perilakunya dapat berubah dengan cepat, tepat, mudah dan benar, baik berkaitan dengan aspek kognitif afektif maupun psikomotor.[15]

Keaktifan siswa selama proses belajar mengajar merupakan salah satu indikator adanya keinginan atau motivasi siswa untuk belajar. Siswa dikatakan memiliki keaktifan apabila ditemukan ciri-ciri perilaku seperti : sering bertanya kepada guru atau siswa lain, mau mengerjakan tugas yang diberikan guru, mampu menjawab pertanyaan, senang diberi tugas belajar, dan lain sebagainya.[16]

Model pembelajaran kooperatif tipe two stay two stray (dua tinggal dua tamu) adalah salah satu model pembelajaran kooperatif yang memberikan kesempatan kepada kelompok membagikan hasil dan informasi kepada kelompok lain. Hal ini dilakukan karena banyak kegiatan belajar mengajar yang diwarnai dengan kegiatan-kegiatan individu.[19]

Lembar observasi yang digunakan untuk mengetahui aktivitas siswa, hal yang di lakukan ialah dengan mengamati siswa dengan 4 indikator yang ada di lembar observsasi yaitu, aktivitas visual, aktivitas lisan, aktivitas menulis,aktivitas berpikir Pelaksanaan pembelajaran geografi yang dilakukan dengan menerapkan model pembelajaran kooperatif tipe two stay two stray adalah sebagai berikut Pada materi pengajaran ini, siswa diharapkan dapat menganalisis materi penginderaan jauh. 
Dalam melaksanakan proses belajar mengajar, peneliti mencoba menjelaskan materi penginderaan jauh menggunakan model pembelajaran kooperatif tipe two stay two stray untuk mendapatkan aktivitas belajar siswa yang maksimal dalam pembelajaran. Berdasarkan analisis pertemuan pertama, diperoleh nilai rata-rata aktivitas siswa dari 32 orang adalah sebesar $46 \%$ degan jumlah skor observasi sebesar 1469 yang hal ini bisa dikatakan kurang aktif bagi siswa, lalu pada pertemuan kedua peneliti terlebih dahulu melakukan tanya jawab untuk mengembangkan aktivitas berpikir para siswa hal sedikit dapat membuat keatifan siswa menigkat karana berdasrkan analisis nilai rata rata siswa yaitu sebesar $56 \%$ atau jumlah skor dari observasi siswa sebesar 1800. Lalu pada pertemuan ketiga peneliti memperisapkan lebih baik lagi dengan berusaha mencari memancing minat serta kreatifitas siswa secara merata, dan juga meminta dan memberi kesempatan lebih kepada siswa yang kuarang aktif untuk bertanya dan menjawab pertanyaan yang diberikan. Berdasarkan hasil analisis pertemuan terakhir atau pertemuan ketiga didapat nilai rata-rata dari 32 siswa sebesar $92 \%$ atau dengan jumlah skor obeservasi sebesar 2944 hal ini dapat dikatakan dalam kategori sangat aktif bagi siswa maka dapat dikatakan penerapan model two stay two stay yang dilakukan di kelas X.IPS.1 Sekolah Menengah Atas Negeri 3 Tebing Tinggi mempunyai pengaruh pada aktivitas belajar siswa.

Berdasarkan hasil analisis data diketahui bahwa rata-rata aktivitas belajar siswa yang diajarkan menggunakan model pembelajaran two stay two stray sebesar 0,65 dengan persentase $65 \%$ yang termasuk dalam kategori aktif. Hasil tersebut menunjukkan bahwa aktivitas belajar siswa menggunakan model pembelajaran two stay two stray pada praktikum geografi materi penginderaan jauh digolongkan aktif.

Hasil penelitian Murjainah menunjukkan bahwa thitung $=5,70$ dan tabel dengan taraf nyata $5 \%$ dan $\mathrm{dk}=52$ diperoleh $\mathrm{t}_{\text {tabel }}=1,668$. Dengan demikian ternyata $t_{\text {hitung }}>t_{\text {tabel }}$, maka hipotesis tentang "ada pengaruh praktikum SIG terhadap kemampuan spasial mahasiswa pendidikan Geografi pada mata kuliah Sistem Informasi Geografi tahun ajaran 2015/2016" diterima. Ini dibuktikan dengan hasil nilai rata-rata kelas 82,61.[4] Selanjutnya penelitian Wibowo menyimpulkan bahwa 1) Pemanfaatan gaya belajar untuk pembelajaran dilakukan melalui tiga tahapan: 
pencarian data gaya belajar siswa, pengelompokan siswa, dan pemberian materi sesuai gaya belajar; 2) Pemanfaatan gaya belajar dapat meningkatkan keaktifan siswa berdasarkan lima indikator yaitu: perhatian, kerjasama dan hubungan sosial, mengemukakan pendapat atau ide, pemecahan masalah, dan disiplin.[20] Penelitian Prasetya dan Zein menyimpulkan bahwa media pembelajaran LKPD yang layak untuk digunakan sebagai media pembelajaran geografi untuk Penginderaan Jauh, karena dapat meningkatkan aktivitas siswa, minat siswa dan mendapat respon positif siswa dalam meningkatkan hasil belajar.[21]

Dilihat dari persentase per indikator aktivitas belajar siswa dapat diketahui bahwa rata-rata persentase indikator 1 yaitu aktivitas visual sebesar $67,19 \%$, rata-rata persentase indikator 2 yaitu aktivitas lisan sebesar 61,46\%, rata-rata persentase indikator 3 yaitu aktivitas menulis sebesar $65,37 \%$, dan rata-rata persentase indikator 4 yaitu aktivitas berpikir sebesar $63,54 \%$.

GRAFIK 1.

RATA-RATA PERSENTASE AKTIVITAS BELAJAR SISWA DILIHAT DARI INDIKATOR AKTIVITAS BELAJAR

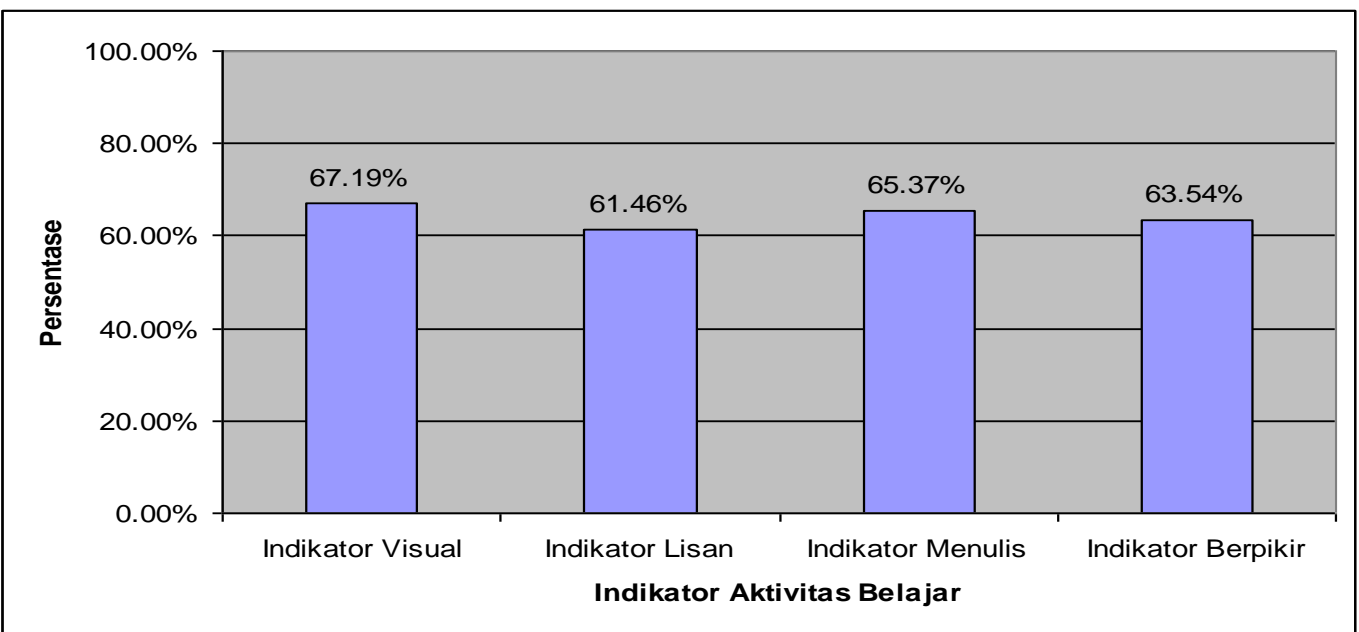

Sumber: Diolah dari data primer tahun 2019.

Kelebihan dari model semua kelas/tingkatan; pembelajaran kooperatif tipe Two Stay Two Stray adalah 1) model pembelajaran ini dapat diterapkan pada kecenderungan belajar siswa menjadi lebih bermakna; 3) model pembelajaran ini lebih berorientasi pada keaktifan 
siswa dalam belajar, dan 4) model pembelajaran kooperatif tipe Two Stay Two Stray membantu meningkatkan motivasi belajar siswa.[22]

\section{KESIMPULAN}

Berdasarkan hasil penelitian dapat disimpulkan bahwa rata-rata persentase indikator 1 yaitu aktivitas visual sebesar $67,19 \%$, rata-rata persentase indikator 2 yaitu aktivitas lisan sebesar 61,46\%, rata-rata persentase indikator 3 yaitu aktivitas menulis sebesar $65,37 \%$, dan rata-rata persentase indikator 4 yaitu aktivitas berpikir sebesar 63,54\%. Secara keseluruhuan dapat diketahui bahwa rata-rata aktivitas siswa pada pertemuan I sebesar 46\% (kategori kurang aktif), pertemuan II sebesar 56\% (kategori aktif), dan pertemuan III sebesar 92\% (kategori sangat aktif).

\section{DAFTAR PUSTAKA}

[1] Sumaatmadja, Nursid. (2011). Metodologi Pengajaran Geografi. Edisi 2. Jakarta: Bumi Aksara.

[2] Permendiknas Nomor 22 Tahun 2006 tentang Standar Isi Mata Pelajaran Geografi.

[3] Kinkeldey, C., (2014). A concept for uncertainty-aware analysis of land cover change using geovisual analytics. ISPRS Int. J. Geo-Inf., Vol. 3, Hal. 1122 -1138.

[4] Murjainah. (2018). Pengaruh Praktikum Sistem Informasi Geografi Terhadap Kemampuan Mahasiswa Pendidikan Geografi
Dalam Memanfaatkan Data Spasial (Studi Kasus Pada Mata Kuliah Sistem Informasi Geografi Tahun Ajaran 2015/2016). Laporan Penelitian Dosen Pendidikan Geografi. Palembang: FKIP Universitas PGRI Palembang

[5] Supinah. (2008). Bagaimana Mengukur Aktivitas Siswa Dalam Pembelajaran?. Modul PPPPTK Matematika.

[6] Hamalik, Oemar. (2001). Proses Belajar Mengajar. Jakarta: Bumi Aksara.

[7] Gino, HJ. dkk. (2008). Belajar Pembelajaran I. Surakarta: Universitas Sebelas Maret.

[8] Dimyati, Mudjiono. (2010). Belajar dan Pembelajaran. Jakarta: Rineka Cipta.

[9] Uno, Hamzah B. (2016). Teori Motivasi dan Pengukurannya Analisis Dibidang Pendidikan. Jakarta: Bumi Aksara

[10] Schowendgerdt, (2007). Remote Sensing: Models and Methods for Image Processing, Third Edition, Elsevier, Amsterdam.

[11] Howari, F.M., Sherif, M.M., Singh, V.P., Al-Asam, M.S., (2007). Dalam : Thangarajan, M. (editor). Groundwater: Resource Evaluation, Augmentation, Contamination, Restoration, Modeling and Management, Springer, Netherland.

[12] Madhok, V., Landgrebe, D.A., (2002). A processing model for remote sensing data analysis, IEEE Life Fellow.

[13] Turdukulov, U.D., Tolpekin, V., Kraak, M.J., (2015). Visual exploration of time series of 
remote sensing data. Citeseerx.ist.psu.edu.

[14] Sardiman, AM. (2014). Interaksi dan Motivasi Belajar Mengajar. Jakarta: Rajawali Pers.

[15] Hanafiah, N. dan Suhana, C. 2010. Konsep Strategi Pembelajaran. Bandung: Refika Aditama.

[16] Rosalia, Tara. (2005). Aktifitas Belajar. (Online) (http://id.shvoong.com/socialsciences) diakses tanggal 13 Maret 2019.

[17] Mulyono, M. (2011). Aktivitas Belajar.

Bandung: Yrama.

[18] Sugiyono. (2016). Metode Penelitian Kuantitatif Kualitataif dan Kombinasi (Mixed. Methods). Bandung: Alfabeta.

[19] Slavin, Robert E. (1995). Cooperative Learning Theory,
Research and Practice. Massachusett, USA: Allymand \& Bacon.

[20] Wibowo. (2016). Upaya Peningkatan Keaktifan Siswa Melalui Pembelajaran Berdasarkan Gaya Belajar di SMK Negeri 1 Saptosari. Jurnal Pendidikan Geografi Vol. 2, Juli 2016.

[21] Prasetya dan Zein. (2017). Implementasi Pembelajaran Penginderaan Jauh. Prosiding Seminar Nasional Tahunan Fakultas Ilmu Sosial Universitas Negeri Medan Tahun 2017 Vol. 1 No. 1 2017, Hal. 555-562.

[22] Santoso, E.B. (2011). Model Pembelajaran Kooperatif Tipe Two Stay Two Stray (TSTS). (Online) (http://raseko.blogspot.com/2011/05/modelpembelajaran-kooperatif-tipetwo.html. (23 Februari 2019). 